\title{
The Study of Lexical Cohesion on Germany Prime Minister's Speech Angela Merkel
}

Stivani Ismawira Sinambela ${ }^{1}$, Nurlela $^{2} \&$ T. Thyrhaya Zein ${ }^{3}$

$1,2,3$ Universitas Sumatera Utara, Indonesia

\begin{tabular}{l}
\hline \hline ARTICLE INFO \\
\hline \hline Article history: \\
Received Dec 30, 2020 \\
Revised Feb 15, 2021 \\
Accepted Mar 17, 2021 \\
\hline
\end{tabular}

Keywords:

Lexical Cohesion, Speech Text, German Language, Angela Merkel

\section{Conflict of Interest:}

None

\begin{abstract}
The Cohesion of discourse is divided into two aspects, namely grammatical Cohesion, and lexical Cohesion. In this study, what will be examined is lexical Cohesion. This study aims to identify forms of lexical Cohesion in the text of the speech of German Prime Minister Angela Merkel. Text analysis of this speech uses Halliday and Hasan's cohesion theory. This research is qualitative. The design in this study is content analysis with descriptive characteristics, namely the presentation of data based on the object of research. The data observed were all lexical elements in cohesive words, phrases, clauses, and sentences. The results showed the percentage of use of lexical Cohesion included (1) 37\% repetition; (2) synonymy 8\%; (3) hyponymy $7 \%$; (4) receives $2 \%$; (5) antonymy $46 \%$. The data shows that the lexical antonym is the most dominant lexical type found in Angela Merkel's speech text.
\end{abstract}

Funding:

None

Corresponding Author: Stivani Ismawira Sinambela, Universitas Sumatera Utara, Medan, Indonesia. Email: vani.sinambela@gmail.com.

\begin{tabular}{ll}
\hline CC) & (C) Stivani Ismawira Sinambela, Nurlela, T. Thyrhaya Zein \\
This is an open access article under the CC BY-SA 4.0 international license.
\end{tabular}

1. Introduction

The element of cohesion use varies from a language to another. It is caused each language has unique characteristics that may be different from the other languages. The elements of Cohesion are needed to build a complete discourse. Halliday and Hasan (1976) stated that the function of Cohesion is as a series of meaning linkages to connect a component in the text (discourse) with what has been previously mentioned. According to that opinion, it can be concluded that several sentences can be considered as a complete text (discourse) if the sentences are related to each other.

One discourse form is speech text. Speech is a form of communication. State speech usually shows special characteristics as a persuasive discourse. It can be seen from the use of words that influence and invite listeners to do what are said. Speech is a communication form carried out by a sender (destination) to several or many recipients (destinations). Therefore, speech is classified into public communication (Schmitt and Viala, 1982: 76). The speech must be adjusted according to the situation and the recipient's condition (destination) in its implementation. The desired message can be received and adequately maintained by the recipient (destination). The speech can be delivered orally (spontaneously) or écrit (reading the text that has been prepared) (Schmitt and Viala, 1982: 79).

Angela Merkel is a politician who served as the first female Prime Minister of Germany. Merkel was elected as Prime Minister (Kanzlerin) of Germany for the fourth time. Merkel's re-election as Prime Minister signifies the very high love and trust the German people have in her. Also, Angela Merkel was also named by 
Forbes magazine as the most influential woman in the world in 2018. Merkel is considered to have played a role in efforts to deal with the European economic crisis. Therefore, Merkel's statement and speech are interesting to study further.

In this study, it was prioritized to analyze the Cohesion of the speech text using Halliday's approach. It is because the approach used by Halliday in analyzing Cohesion is considered in more detail, which is described by the division of Cohesion into (1) grammatical cohesion, which is manifested through reference, substitution, ellipsis, conjunction, and (2) lexical Cohesion which is manifested through repetition, synonymy, hyponymy/hyperonym, receive, antonymy. Furthermore, this study only focused on the lexical Cohesion found in Angela Merkel's speech text.

\section{Method}

This study conducted two approaches, namely methodological and theoretical approach. The methodological approach is a qualitative descriptive approach that aims to explain German grammatical and lexical Cohesion markers in Angela Merkel's Speech Text. Bogdan and Taylor (1992: 21-22) explained that qualitative research is a research procedure that produces descriptive data in the form of words or writings and the people's behavior being observed. The qualitative approach was expected to produce in-depth descriptions of speech, writing, and the observable behavior of a particular individual, group, community, and organization in a particular context setting that were examined from a comprehensive, comprehensive, and holistic perspectives.

The second approach is the theoretical approach. The theoretical approach in this study used a discourse analysis approach. Biryani (2003: 3) stated that discourse analysis is an activity to study discourse internally and externally. From an internal perspective, discourse is studied from its type, structure, and relationship of its parts. From an external perspective, discourse is studied in terms of the relation between the discourse and the speaker, the things discussed, and the talking partners. The discourse analysis aims to reveal the rules of language that construct discourse, produce discourse, understand discourse, and symbolize something in the discourse. Discourse analysis aims to provide discourse (as one of the exponents of language) in its function as a means of communication. The discourse used in this study is the German speech text by the German Prime Minister, Angela Merkel, which was conducted to find the cohesive elements of the speech text.

\subsection{Lexical Cohesion}

Cohesion is one of the elements in discourse that makes the discourse intact and understandable. According to Tarigan (1987: 96), Cohesion is a formal aspect of language in discourse (the relationship appearing in the form). Furthermore, Ramlan (1993: 10) defines Cohesion as Cohesion in the field of the form. Cohesion is a syntactic organization, and it is a container for sentences that are arranged coherently and densely to produce speech. Lexical Cohesion is the relationship between elements in discourse semantically. In this case, to produce a unified discourse, the speaker or writer can select the words according to the content of the discourse in question. A cohesive relationship is created based on linguistic aspects, with a harmonious choice of words, which states the meaning or semantic relationship between one lingual unit and another lingual unit in discourse (Sumarlam, 2008: 35). The lexical discourse elements that form cohesion bonds are usually expressed through the level of the relationship itself. In this case, (Halliday and Hasan, 1976: 288) stated it as the Relatedness of the lexical item. A more substantial level of relationship states that the lexical elements form a cohesion bond.

Lexical Cohesion is divided into two large groups, namely reiteration, and collocation. Reiteration is the repetition of two words with the same reference, or it can be said that it has a coreferential relationship (coréférence). The cohesion tools include; (a) repetition, namely the exact word repetition with the same reference in the discourse; (b) synonymy, which is a set of words that have the same meaning; and (c) hyponymy, which is a relationship that shows the inclusion of meaning (inclusive) between lexical elements. Collocation is the harmony or compatibility between a word and the words that accompany it (Palmer, 1976: 76). Meanwhile, Robin (1964: 63) stated that the definition of collocation is the tendency of a word to join certain words in a sentence. Collocation has cohesion tools which include: (a) antonymy, namely the relationship between a lexeme that contradicts its meaning with other lexemes; (b) receive is the relationship between the whole and the parts that makeup it.

\section{Results and Discussion}

Based on the analysis of Angela Merkel's speech text, it was found that the types of lexical are reiteration and collocation. In this speech text, there are three markers of reiteration lexical Cohesion, namely 17 findings of 
repetition, four synonyms (synonym), three hyponymies (top-down relationship); and lexical collocation cohesion found two markers, namely receive (object brand) as many as one finding and antonymy (opposite words) as many as 21 findings.

Table 1. Lexical Cohesion

\begin{tabular}{llll}
\hline No. & Lexical Form & Total & Percentage \\
\hline 1. & Repetition & 17 & $37 \%$ \\
2. & Synonym & 4 & $8 \%$ \\
3. & Hyponymy & 3 & $7 \%$ \\
4. & Receive & 1 & $2 \%$ \\
5. & Antonymy & 21 & $46 \%$ \\
& TOTAL & 46 & 100 \\
\hline
\end{tabular}

\subsection{Repetition}

Lexical repetition (repetition) is the repetition of a lexical element, which does not have to be in the same morphological form. The repetition of a lexical element can be in the form of addition, omission, or change in the bound morpheme (affix). In the text of Angela Merkel's speech in Germany, there were 17 findings. The following data are the findings of repetitive lexical Cohesion.

PAM (34): Dieses Abkommen ist alles andere als ideal; aber der Iran hält sich nach allen Erkenntnissen der Internationalen Atomenergiebehörde an die Verpflichtungen aus diesem Abkommen.

The agreement is far from ideal, but Iran complied with the agreement following findings from the international energy agency.

From the data above, there is a repetition of Abkommen's "agreement" at the end of a sentence with the same word at the beginning of the sentence. Repetition was conducted to maintain the integrity and continuity of the information conveyed so that there was no misunderstanding.

\subsection{Synonymy}

Lexical synonymy (synonym) is a relationship between words (phrases or sentences) with the same meaning. In contrast, close synonymy is a relationship between words with different meanings but are close or similar. Synonymy can occur between words that come from regional languages, national languages, and foreign languages. It was found that there are only four findings in Angela Merkel's speech text. The following data are the findings of synonymy.

PAM (42): ...dass das Leben der Menschen in Syrien unter einem unglaublichen Schrecknis abläuft.

PAM (43): Die Hälfte der Bürgerinnen und Bürger Syriens ist inzwischen auf der Flucht...

(42) ... that the people's lives in Syria are in a perilous situation. (43) Half of Syrians are currently fleeing the country ...

From the data above, it can be concluded that der Menschen "people" and der Bürgerinnen und Bürger "citizen" are synonyms because they both mean the same thing, and they are interchangeable. The two phrases have the same meaning. The use of this synonym was to avoid repeating the same word in a paragraph.

\subsection{Hyponymy}

Hyponymy lexical (top-down relationship) is defined as a language unit (words, phrases, sentences) whose meaning is considered the meaning part of another lingual unit. The lingual element or unit, which includes several elements or lingual units that are hyponymous, is called "hypertime" or subordinate. There are three findings found in Angela Merkel's speech in German. The following data are the hyponymy lexical cohesion findings.

PAM (24): Nach dem Arabischen Frühling, der von vielen auch als arabisches Beben bezeichnet wird, ist die Region vor unserer Haustür unruhig geworden: der Bürgerkrieg in Syrien seit 2011, der Sturz von Gaddafi in Libyen mit dem Zerfall der staatlichen Ordnung, 2014 die Annexion der Krim, die Probleme in der Ostukraine, 2014 der IS in Syrien und im Irak, der Völkermord an den Jesiden im Irak und die in Rakka, geplanten Attentate, die Paris - „Charlie Hebdo“ - so erschüttert haben. 
After the Arab Spring, which was perceived as an event that shook the Arab, the areas at our doorsteps became restless: civil war in Syria since 2011, the overthrow of Gaddafi in Libya at the same time as the disintegration of the government level, the conquest of Crimea in 2014, the problems in East Ukraine, the emergence of ISIS in Syria and Iraq, the genocide in Yazidis in Iraq and in Rakka, the premeditated murder that rocked Paris "Charlie Hebdo."

Based on the findings above, it can be concluded that the hypernim or subordinate of the sentence is Arabischen Frühling "Arab Spring”. Meanwhile, the Arabischen Frühling incidents as a hyponym, namely der Bürgerkrieg in Syrien, der Sturz von Gaddafi in Libyen, der IS in Syrien und im Iraq, der Völkermord an den Jesiden im Iraq und die in Rakka. The relationship between subordinate elements or between words that are members of the hyponym is called "kohiponym".

\subsection{Receive}

The lexical receives the relationship between the name (brand) for other associated objects or which become its attributes. In metonymy, the name or brand of an object is used to refer to the object itself. In the text of Angela Merkel's speech in German, there is one finding found. The following finding is the receive lexical found.

PAM (119) :Wir müssen überlegen, wie wir wirtschaftlichen Schwung in die Dinge bringen, wie wir auch mit Kreditinstrumenten, mit Hermes und vielem anderen mehr, noch mehr Investitionen in Afrika möglich machen, aber natürlich auch durch das, was Wolfgang Schäuble in der G-20-Präsidentschaft gemacht hat: durch bessere Rahmen-bedingungen - Compact with Africa - ein gutes Investitionsumfeld schaffen.

We need to think about how we can bring economic momentum into things like we can make more investment in Africa possible with credit instruments, with Hermes, and more, but of course with what Wolfgang Schauble did at the G-20 Presidents' Meeting: through a better framework -Compact with Africa- create a bright investment climate.

The word Hermes above is a brand that has been associated with the mention of bags made from crocodile skin from Africa. Although investing in Africa is not only the Hermes trademark.

\subsection{Antonymy}

The antonymy lexical is a relationship between words whose meanings are contradictory or contradictory. Antonymy lexical cohesion can be interpreted as another name for something or something else; or lingual units whose meaning is opposite or in opposition to the other lingual units.

Antonym is also called the opposition to meaning. The opposite meaning includes concepts that are opposite to those that only have contrasting meanings. In Angela Merkel's speech in German, only 21 findings were found. The antonymy findings are shown below.

PAM (43) :Die Hälfte der Bürgerinnen und Bürger Syriens ist inzwischen auf der Flucht: ein großer Teil innerhalb Syriens, ein anderer Teil außerhalb Syriens.

Half of the population (men and women) of Syria are currently fleeing their country: most are still trapped in Syria, and some have managed to get out from Syria.

The data above shows a relationship between words with contradictory meanings because the opposite word Bürgerinnen (female population) is Bürger (male population). Furthermore, the innerhalb Syriens phrase "trapped in Syria" is a condition that is the opposite of the außerhalb Syriens phrase "get out from Syria."

The existence of antonymy cohesion shows that the parts of the sentences are related to each other.

\subsection{Lexical Cohesion in Angela Merkel's Speech Text}

Type of Lexical Cohesion in Angela Merkel's speech text discourse are manifested in the form of repetition, close synonym/synonym, hyponymy, antonymy, and receive. The lexical discourse elements formed a cohesion bond expressed through the level of relationship in the discourse itself. In the speech text discourse, 46 data are showing lexical Cohesion. Based on the results of data analysis, it can be concluded that in the lexical Cohesion, the most dominant found is lexical antonymy as many as 21 findings.

First, repetition in discourse is found in many things in the form of objects, places, and activities that have an essential role in forming political speech texts that serve to invite society as a whole. Repetition serves to emphasize essential things in the speech text that the speaker wants to convey. Angela Merkel is the prime minister of Germany. Furthermore, in Angela Merkel's speech text discourse, 17 findings using repetition 
were found. For example, the finding of the Abkommen (agreement) in PAM (34) is the end of a sentence with the same word as the beginning of the sentence.

Second, the type of lexical Cohesion in the form of synonym in the discourse is realized in synonyms and close synonyms. Lexical synonymy (synonym) is a relationship between words (phrases or sentences) with the same meaning. In contrast, close synonymy is a relationship between words with different meanings but are close or similar. There are four findings of synonymous lexical Cohesion found. For example, der Menschen "people" and der Bürgerinnen und Bürger "citizen" as synonyms because they both mean the same thing, and they are interchangeable. It was conducted to avoid repeating the same word in the paragraph.

Third, there are only three types of hyponymy lexical Cohesion in the meaning of lingual units in the form of one language (words, phrases, sentences). Lingual elements or units that include several elements or lingual units that are hyponymous are called "hypernym" or subordinate. For example, Arabischen Frühling "Arab Spring".

Fourth, the type of lexical Cohesion of receive is the relationship between the name (brand) for other associated objects or which become its attributes. In receive lexical, the name or brand of an object refers to the object itself.

In the speech discourse, there is only one finding found regarding the lexical Cohesion of receive. For example, the use of the word Hermes in PAM (119) in Angela Merkel's speech, a brand has been associated with the mention of bag made of crocodile skin from Africa.

Fifth, the lexical antonymy is a relationship between word (s) whose meaning is contradictory or contradictory. For example, the word Bürgerinnen (female population) and Bürger (male population).

\section{Conclusion}

Based on the results of data analysis in this study, several conclusions can be drawn regarding the lexical Cohesion found in Angela Merkel's speech text. First, lexical Cohesion is not only limited to the semantic relationship between one lexeme and another. However, it can also occur between lexemes and the other lexemes, or a combination of lexemes with a combination of lexemes in the form of phrases, clauses, and sentences. The proportion of data found shows that the antonymy is the most common lexical cohesion marker that appeared in the data source 21 times.

The dominance of Lexical Cohesion in the form of antonymy in Angela Merkel's speech text can be related to the ideological perspective of Angela Merkel from the German Conservative Party (CDU), which still views that there are only two genders, namely male (masculine) and female (feminism). According to this, the type of lexical antonymy found in Angela Merkel's speech is the opposite of the word in terms of gender. Even though the German vocabulary has a common word to describe "the people," namely Staatsbürger, Angela Merkel selected not to use the word, but Bürgerinnen (female population) and Bürger (male population).

\section{References}

Anahamu, Maryati. 2016. Kohesi dan Koherensi Teks Pidato "APEC CEO SUMMIT 2014" Oleh Joko Widodo. Makasar: Universitas Sam Ratulangi.

Bahaziq, Afnan. 2016. Cohesive Devices in Written Discourse: A Discourse Analysis of a Student's Essay Writing. Journal English Language Teaching, 9 (7), 112-119.

Dieckmann, W. (1981) Politische Sprache. Politische Kommunikation. Heidelberg: Carl Winter Universitätsverlag.

Engel, Ulrich. 1988. Deutsche Grammatik. Heidelberg: Julius Groos Verlag.

Grebe, Paul et. al. 1993. Die Grammatik. Mannheim: Grebe -Verlag

Gross, Harro. 1988. Einführng in die germanictische Linguistik. München: IudicimVerlag $\mathrm{GmbH}$

Halliday dan Hasan. 1989/1992. Bahasa, Konteks, dan Teks. Terjemahan Language, Text, and Context oleh Asruddin Baroru Tou. Yogyakarta: Gajah Mada. University Press.

Menzel, Katrin. 2016. Textkompetenz in Fremdsprachenvermittlung und Übersetzer-ausbildung - ein korpusbasierterSprach- und Registervergleich zu Kohäsions-mitteln im Englischen und Deutschen.Universität des Saarlandes. 
Rostami, G., \& Gholami, H. 2016. A Contrastive Study of Lexical Cohesion Used in Sport Texts of Washington Times and Tehran Times Newspapers Written by English Native and Non-native Iranian Writers. Journal of Applied Linguistics and Language Research, 3(1), 121-132.

Simanjuntak, Dumaria. 2008. Pemarkah Kohesi Sebagai Penyelaras Wacana: Kajian Terhadap Kumpulan Cerita Pendek Harian Kompas. Tesis. Program Pascasarjana Universitas Indonesia. Jakarta.

Simanjuntak, Berliana. 2017. Kohesi dalam Teks Pidato Kenegaraan Presiden RI Susilo Bambang Yudhoyono dan Joko Widodo. Tesis. Program Pascasarjana Universitas Sumatera Utara. 